\title{
State Environmental Expenditures and Their Correlation with Seven Econometric Factors
}

\author{
Robert P. Blauvelt (Corresponding author) \\ GEI Consultants, 1 Greenwood Avenue, Montclair, New Jersey 07042, United States of \\ America
}

Tel: 973-873-7127; Fax:973-509-9625Ｅ- mail: rblauvelt@ geiconsultants.com

Received: Sep. 28, 2014 Accepted: November 13, 2014 Published: December 7, 2014

doi:10.5296/jee.v5i2.6374 URL: http://dx.doi.org/10.5296/jee.v5i2.6374

\begin{abstract}
Most states assume administrative ownership of federal environmental programs and tailor them to match their special jurisdictional needs. However, with primacy comes a performance obligation and, given declining federal EPA budgets and staffing levels, the monitoring and enforcement burdens associated with environmental regulations have shifted to the states. As the most visible regulatory and administrative force responsible for protecting the nation's environment, the ability of state DEPs, DEQs, and DECs to effectively serve its citizens and constructively interact with the regulated community is critically dependent on the resources made available to it. Without adequate funding, the compliance and enforcement components of state environmental agency programs become mere paper tigers - threatening but ineffectual and without real substance.

What factors influence the amount of spending states direct towards environmental programs? For the purposes of this paper, non-capital environmental expenditures between 2000 and 2009, adjusted to 2010 dollars, were chosen as the dependent variable for 49 states, exclusive of Hawaii because of its unique ecological and economic setting. Seven data sets were selected as independent variables; those possibly explaining or accounting for a state's environmental spending choices. These include: population, total state expenditures, Gross State Product or GSP, the manufacturing and mining sectors of Gross State Product (M\&M GSP), unemployment rates, total amounts (in pounds) of chemicals regulated by the Toxic Release Inventory (TRI) for discharges to air (fugitive and point source) and surface water, and health ranking score by state.
\end{abstract}

A Pearson's product moment correlation coefficient was used to compare environmental expenditures for each state with the seven data sets. Population (in 15 states), GSP (in 21 


\section{Macrothink}

states), M\&M GSP (in 12 states) and total state expenditures (in 17 states) are the independent variables that seem to have the most connection with environmental expenditures. Each of these ties directly to the overall financial capacity of a state and they are roughly split in defining positive and negative relationships between the variables.

Keywords: Environmental expenditures, Population, Gross state product, Unemployment, Health ranking 


\section{Introduction}

Since the 1970s, U.S. environmental legislation has been based on the integration of nationwide environmental policy objectives with their administration, enforcement, and sometimes enhancement by the states (Welborn, 1988; Lester and O'M. Bowman, 1989). Congress and the U.S. Environmental Protection Agency (EPA) enacted environmental laws and regulations with baseline performance and compliance requirements that preempted local rules, although states are able to set more restrictive standards (Steinway and Botts, 2005). With initial funding and ongoing technical support from Washington, states became responsible for administering, permitting, and enforcing federally mandated environmental programs. EPA reluctantly reasserts control only when it finds that state requirements are not consistent with federal goals (Woods, 2005).

Obtaining primacy from EPA - assumption of authority for implementation and enforcement of an environmental program - is a complex process, requiring state legislative action that includes establishment of long-term, stable funding mechanisms (Crotty, 1987). A state's reason to seek primacy can range from a desire to reduce the regulatory burden on its industries through less aggressive enforcement than might take place under federal management to a need for bureaucratic control (Lester and O'M. Bowman, 1989). Regardless of motivation, most states assume administrative ownership of federal environmental programs and seek to tailor them to match their special jurisdictional needs (Steinway and Botts, 2005).

However, with primacy comes a performance obligation for a state's environmental agency. Between 2000 and 2010 EPA budgets and staffing levels, the number of FTEs or full time equivalent employees, remained flat (Figure 1) and the monitoring and enforcement burdens associated with environmental regulations shifted to the states.

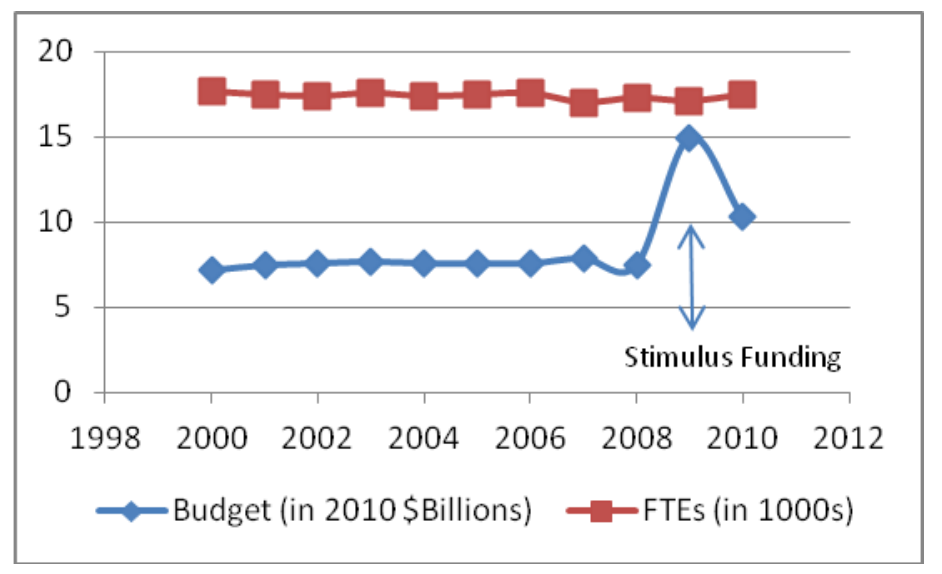

Figure 1. EPA budgets and number of full-time (equivalent) employees

Analyses prepared by ECOS: Environmental Council of the States (Brown and Green, 2001 and Blakeslee and Rong, 2006) found that state environmental protection agencies "...were making substantial and effective contributions to environmental enforcement...”. ECOS determined that state environmental agencies were responsible for collection of 94 percent of 
environmental quality data in six EPA national compliance and enforcement tracking systems.

As the most visible regulatory and administrative force responsible for protecting the nation's environment, the ability of state DEPs, DEQs, and DECs to effectively serve its citizens and constructively interact with the regulated community is critically dependent on the resources made available to it. Without adequate funding, the compliance and enforcement components of state environmental agency programs become mere paper tigers - threatening but ineffectual and without real substance.

\section{Dependent Variable}

What factors influence the amount of spending states direct towards environmental programs? Expenditures for environmentally-related activities have long been recognized as a valid (but not the only) proxy representing a state's commitment or level of dedication to these types of influential socio and econometric policies (Patten, 1998; Newmark and Witko, 2007; Wood and Konisky, 2012). For the purposes of this paper, non-capital environmental expenditures between 2000 and 2009, adjusted to 2010 dollars, were chosen as the dependent variable. These expenditures include services and costs related to the regulation of natural resources, air quality, water quality, sanitary engineering, and other environmental activities. They exclude capital or "one-off" environmental projects such as wastewater treatment plant construction or water supply/management projects. Environmental spending data is readily accessible and easily comparable across jurisdictions and is reactive or sensitive over the short term to the budgetary preferences of legislative bodies which, presumably, are not insulated from the constituents they purport to serve. Data sets for 49 states, exclusive of Hawaii because of its unique ecological and economic setting, were obtained from U.S. Census Bureau and are available at http://www.census.gov/govs/local.

\section{Independent Variables}

Seven data sets were selected as independent variables; those possibly related to a state's environmental spending choices. These include, for the years 2000 through 2009, the following:

\subsection{Base State Populations}

These are population counts or assessments compiled by the US Census Bureau and used as the starting point in that year's population estimating process. They can be the most recent updated census count or the estimate for a previous date within the same general period.

\subsection{Total State Expenditures}

These are payments (i.e., total state spending normalized to 2010 dollars) by a government and its agencies net of correcting transactions and recoveries or refunds, and excluding government-operated enterprises (e.g., lotteries), utilities, and public trust (pension) funds.

\subsection{Gross State Product or GSP}

This is an inflation adjusted measure (in 2010 dollars) of each state's production (all goods 
and services) based on a weighted average of national prices for those products and services produced within each state.

\subsection{Manufacturing and Mining Sectors of Gross State Product (M\&M GSP)}

The manufacturing sector comprises establishments engaged in the mechanical, physical, or chemical transformation of materials, substances, or components into new products; including assembling of component parts. The mining sector comprises establishments that extract naturally occurring mineral solids (e.g., coal and ores), liquid minerals (crude oil), and gases. The term mining is used in the broad sense to include quarrying, well operations, beneficiating (e.g., crushing, screening, washing, and flotation), and other preparation customarily performed at the mine site, or as a part of mining activity. These values also were adjusted to 2010 dollars.

\subsection{Average Annual, Seasonally Adjusted Non-Farm Unemployment Rates}

These rates include employed persons - those who did any work at all for pay or profit in the survey period or worked 15 hours or more without pay in a family business during the survey period - and unemployed persons - those who did not work at all (in the survey period) and have actively looked for a job sometime in the four-week period ending with the survey period.

\subsection{Toxic Release Inventory}

Total amounts (in pounds) of chemicals regulated by the Toxic Release Inventory (TRI) for discharges to air (fugitive and point source) and surface water. The TRI is a publicly available database compiled by EPA that contains information provided by manufacturers on the amount of certain chemical releases and other waste management activities. It is prepared annually and includes federal facilities. The inventory was mandated by the Emergency Planning and Community Right-to-Know Act of 1986 and expanded by the Pollution Prevention Act of 1990.

\subsection{Health Ranking Score by State}

This is a weighted ranking schema compiled on a state-by-state basis since 1990. The ranking system assesses information on individual behaviors, public and health policies, community and environmental conditions, and clinical care data to develop a comprehensive view of health patterns and conditions within each state. It is published jointly by United Health Foundation, American Public Health Association, and Partnership for Prevention.

These seven data sets have been evaluated to determine whether a single variable or combination of variables can be used to forecast or presage a response to a state's environmental spending proclivities. While demonstrating causation could not be done in any meaningful way through such a limited examination of the data sets, exploring the apparent influence or connection (if any) between population, GSP, unemployment, health ranking, etc., on environmental expenditures is a more achievable study objective.

There are several reasons to focus on environmental expenditures as the dependent variable and a potential state agency performance indicator. The financial resources a state is willing 
to commit to monitor and maintain the integrity of its environment is a much clearer statement of its priorities than other, perhaps more confounding signals such as per capita income or average educational level (Bacot and Dawes, 1997; Newmark and Witco, 2007; Konisky and Woods, 2012). In effect, environmental expenditures may serve as a surrogate for the level or degree of engagement its regulatory agency has with the business community and other stakeholders.

Environmental expenditures are of a scale, averaging $\$ 470$ million per year per state between 2000 and 2009, that changing them should allow for effects to be seen in other parts of a state's economic performance. Health care, education, and public safety command more significant places in most state budgets and changes in those variables over similar periods have been analyzed regularly as predictors of policy performance and constituent service ability (GAO, 1998; Mohapatra and Mishra, 2011; James et al., 2012). The same should hold true for environmental expenditures.

Finally, other environmental metrics may be too narrowly focused to connect or easily discern their possible connection with a state's policy objectives. For example, fines and enforcement actions, while important and regularly used to gauge environmental agency performance, may not be strong measures of effectiveness (Giles, 2013; Mintz, 2013). No governmental agency, environmental or not, wants to waste precious resources chasing the approximately ten percent of bad actors that are responsible for 90 percent of non-compliance issues. The real influence state environmental agency policy has are not measureable by enforcement or inspection activity but rather through constituent outreach and education in order to achieve, maintain, or enhance compliance (Stafford, 2008; Toffel and Short, 2011).

\section{Comparison Methodology}

A Pearson's product moment correlation coefficient was used to compare environmental expenditures (EE) for each state with seven data sets. A Pearson's product moment (R) is a dimensionless index that ranges from -1 to 1 inclusive and reflects the extent of a linear relationship between two data sets. For those correlations observed between -0.7 or +7 and higher, two-tailed significance testing was done using a critical value of 2.306 at $\alpha=0.05$ with eight degrees of freedom. Table 1 summarizes calculated correlation coefficients for each of the 49 states evaluated.

Table 1. Summary of Data Set Correlations with Environmental Expenditures (values in bold typeface ind icate a correlation above \pm 0.7 )

\begin{tabular}{|c|c|c|c|c|c|c|c|c|}
\hline State & Pop. & $\begin{array}{c}\text { State } \\
\text { Expend }\end{array}$ & GSP & $\begin{array}{c}\text { GSP } \\
\text { Mining } \\
\text { \& Man }\end{array}$ & $\begin{array}{c}\text { Une mp } \\
\text { Rate }\end{array}$ & $\begin{array}{c}\text { Hlth } \\
\text { Rank }\end{array}$ & $\begin{array}{c}\text { TRI } \\
\text { Air }\end{array}$ & $\begin{array}{c}\text { TRI } \\
\text { Water }\end{array}$ \\
\hline Alabama & $\mathbf{1 . 0}$ & 0.6 & $\mathbf{0 . 7}$ & 0.3 & 0.2 & -0.2 & $\mathbf{- 0 . 7}$ & 0.5 \\
\hline Alaska & 0.2 & -0.1 & 0.0 & -0.1 & 0.0 & 0.0 & 0.2 & 0.0 \\
\hline Arizona & $\mathbf{0 . 7}$ & $\mathbf{0 . 7}$ & $\mathbf{0 . 7}$ & -0.3 & -0.3 & -0.3 & $\mathbf{- 0 . 7}$ & $\mathbf{0 . 8}$ \\
\hline Arkansas & $\mathbf{- 0 . 9}$ & $\mathbf{0 . 8}$ & $\mathbf{- 0 . 9}$ & 0.1 & -0.5 & 0.4 & 0.4 & -0.2 \\
\hline California & $\mathbf{0 . 9}$ & $\mathbf{1 . 0}$ & $\mathbf{0 . 9}$ & 0.3 & 0.3 & 0.5 & $\mathbf{- 0 . 9}$ & 0.5 \\
\hline
\end{tabular}


MI Macrothink

Journal of Environment and Ecology ISSN 2157-6092 2014, Vol. 5, No. 2

\begin{tabular}{|c|c|c|c|c|c|c|c|c|}
\hline State & Pop. & $\begin{array}{c}\text { State } \\
\text { Expend }\end{array}$ & GSP & $\begin{array}{c}\text { GSP } \\
\text { Mining } \\
\text { \& Man } \\
\end{array}$ & $\begin{array}{c}\text { Une mp } \\
\text { Rate }\end{array}$ & $\begin{array}{l}\text { Hlth } \\
\text { Rank }\end{array}$ & $\begin{array}{l}\text { TRI } \\
\text { Air }\end{array}$ & $\begin{array}{c}\text { TRI } \\
\text { Wate r }\end{array}$ \\
\hline Colorado & 0.4 & 0.4 & 0.4 & 0.5 & 0.3 & 0.3 & -0.1 & -0.6 \\
\hline Connecticut & -0.6 & 0.2 & -0.8 & -0.8 & -0.3 & 0.5 & 0.4 & 0.0 \\
\hline Delaware & 0.8 & 0.8 & 0.8 & 0.3 & 0.1 & -0.7 & -0.3 & 0.5 \\
\hline Florida & -0.1 & -0.1 & 0.0 & 0.2 & -0.3 & 0.2 & 0.1 & 0.0 \\
\hline Georgia & -0.8 & -0.8 & -0.9 & 0.7 & -0.5 & -0.4 & 0.6 & -0.4 \\
\hline Idaho & -0.6 & 0.6 & -0.7 & -0.3 & 0.0 & -0.4 & 0.6 & 0.3 \\
\hline Illinois & -0.9 & -0.7 & -0.9 & 0.6 & -0.3 & 0.5 & 0.4 & 0.1 \\
\hline Indiana & -0.6 & -0.6 & -0.6 & -0.3 & -0.1 & -0.4 & 0.1 & 0.2 \\
\hline Iowa & -0.2 & -0.1 & -0.6 & -0.8 & -0.1 & 0.1 & 0.7 & -0.8 \\
\hline Kansas & 0.3 & 0.4 & 0.1 & -0.1 & 0.7 & 0.4 & 0.0 & -0.2 \\
\hline Kentucky & -0.4 & -0.6 & -0.3 & 0.9 & -0.7 & 0.5 & 0.2 & 0.0 \\
\hline Louisiana & 0.2 & 0.8 & 0.6 & 0.4 & 0.1 & -0.7 & -0.1 & 0.0 \\
\hline Maine & 0.0 & 0.3 & -0.1 & -0.3 & 0.1 & 0.2 & -0.3 & 0.5 \\
\hline Maryland & 0.2 & 0.5 & 0.6 & 0.1 & 0.7 & -0.9 & 0.0 & 0.0 \\
\hline Massachusetts & -0.4 & -0.4 & -0.5 & 0.6 & -0.3 & -0.6 & 0.7 & -0.6 \\
\hline Michigan & 0.0 & 0.1 & -0.8 & 0.8 & -0.6 & -0.4 & 0.4 & -0.3 \\
\hline Minnesota & -0.9 & -0.7 & -0.9 & -0.1 & -0.4 & -0.3 & 0.6 & -0.5 \\
\hline Mississippi & 0.2 & 0.1 & 0.1 & 0.3 & -0.3 & 0.0 & 0.4 & 0.0 \\
\hline Missouri & 0.2 & 0.1 & 0.1 & -0.2 & 0.2 & 0.2 & 0.2 & -0.5 \\
\hline Montana & 0.2 & 0.3 & 0.2 & -0.1 & -0.2 & 0.2 & -0.5 & 0.5 \\
\hline Nebraska & 0.6 & 0.6 & 0.5 & 0.3 & 0.4 & 0.2 & 0.0 & -0.7 \\
\hline Nevada & 0.7 & 0.7 & 0.8 & 0.7 & 0.0 & -0.2 & -0.6 & 0.6 \\
\hline N Hampshire & 0.6 & 0.8 & 0.7 & -0.4 & 0.3 & 0.4 & -0.5 & 0.4 \\
\hline New Jersey & 0.0 & 0.0 & -0.2 & 0.0 & 0.3 & 0.1 & -0.2 & 0.3 \\
\hline New Mexico & 0.4 & 0.3 & 0.5 & 0.5 & 0.2 & -0.3 & -0.6 & 0.6 \\
\hline New York & -0.6 & -0.6 & -0.7 & 0.4 & 0.0 & 0.6 & 0.5 & 0.1 \\
\hline N Carolina & -0.5 & -0.5 & -0.6 & 0.0 & 0.3 & 0.6 & 0.6 & -0.6 \\
\hline N Dakota & 0.3 & 0.8 & 0.9 & 0.9 & 0.6 & 0.4 & -0.8 & 0.6 \\
\hline Ohio & 0.8 & 0.6 & 0.8 & -0.4 & 0.2 & -0.3 & -0.7 & 0.6 \\
\hline Oklahoma & 0.6 & 0.5 & 0.5 & 0.5 & 0.6 & 0.4 & -0.1 & -0.1 \\
\hline Oregon & 0.6 & 0.7 & 0.5 & 0.4 & 0.6 & 0.0 & -0.8 & 0.4 \\
\hline Pennsylvania & -0.9 & -0.9 & -0.9 & 0.9 & -0.4 & -0.4 & 0.8 & -0.5 \\
\hline R Island & 0.4 & -0.4 & -0.5 & 0.6 & -0.8 & 0.5 & 0.2 & 0.4 \\
\hline S Carolina & -0.4 & -0.5 & -0.5 & 0.5 & -0.3 & 0.5 & 0.7 & -0.8 \\
\hline S Dakota & 0.9 & 0.9 & 0.9 & 0.6 & 0.4 & 0.4 & -0.2 & -0.7 \\
\hline Tennessee & 0.8 & 0.6 & 0.6 & -0.8 & 0.8 & 0.0 & -0.2 & -0.4 \\
\hline Texas & -0.3 & -0.4 & -0.3 & -0.1 & -0.2 & -0.1 & 0.0 & 0.3 \\
\hline Utah & -0.5 & -0.3 & -0.6 & -0.7 & 0.4 & -0.6 & -0.4 & 0.6 \\
\hline Vermont & -0.7 & -0.5 & -0.6 & 0.6 & -0.6 & 0.5 & -0.2 & 0.8 \\
\hline
\end{tabular}




\begin{tabular}{|c|c|c|c|c|c|c|c|c|}
\hline State & Pop. & $\begin{array}{c}\text { State } \\
\text { Expend }\end{array}$ & GSP & $\begin{array}{c}\text { GSP } \\
\text { Mining } \\
\text { \& Man }\end{array}$ & $\begin{array}{c}\text { Une mp } \\
\text { Rate }\end{array}$ & $\begin{array}{c}\text { Hlth } \\
\text { Rank }\end{array}$ & $\begin{array}{c}\text { TRI } \\
\text { Air }\end{array}$ & $\begin{array}{c}\text { TRI } \\
\text { Wate r }\end{array}$ \\
\hline Virginia & $\mathbf{- 0 . 9}$ & $\mathbf{- 0 . 9}$ & $\mathbf{- 0 . 8}$ & $\mathbf{0 . 9}$ & $\mathbf{- 0 . 7}$ & 0.4 & 0.5 & -0.1 \\
\hline Washington & 0.2 & 0.5 & 0.2 & 0.3 & $\mathbf{0 . 7}$ & -0.4 & 0.0 & -0.2 \\
\hline W Virginia & -0.3 & -0.6 & $\mathbf{- 0 . 7}$ & -0.4 & 0.1 & 0.3 & $\mathbf{0 . 9}$ & $\mathbf{- 0 . 7}$ \\
\hline Wisconsin & 0.3 & 0.4 & 0.3 & -0.3 & 0.1 & 0.1 & -0.5 & 0.5 \\
\hline Wyoming & $\mathbf{0 . 8}$ & $\mathbf{0 . 9}$ & $\mathbf{0 . 8}$ & $\mathbf{0 . 8}$ & 0.2 & -0.6 & $\mathbf{0 . 8}$ & $\mathbf{- 0 . 8}$ \\
\hline
\end{tabular}

\section{Findings}

Table 2 lists those states and categories where correlations with EE were found to be present across the data sets.

Table 2. Summary of correlations to environmental expenditures by data set

\begin{tabular}{|c|c|}
\hline Category & State \\
\hline Health Rankings & $\begin{array}{l}\text { Positive: None } \\
\text { Negative: Delaware (-0.7); Louisiana (-0.7); Maryland (-0.9) }\end{array}$ \\
\hline Unemployment Rate & $\begin{array}{l}\text { Positive: Kansas (0.7); Maryland (0.7); Tennessee (0.8); and } \\
\text { Washington (0.7) } \\
\text { Negative: Kentucky (-0.7); and Virginia (-0.7) }\end{array}$ \\
\hline TRI Chemicals - Water & $\begin{array}{l}\text { Positive: Arizona (0.8); Vermont }(0.8) \\
\text { Negative: Iowa (-0.8); Nebraska (-0.7); South Carolina (-0.8); } \\
\text { South Dakota (-0.7); West Virginia } \quad(-0.7) \text {; Wyoming }(-0.8)\end{array}$ \\
\hline TRI Chemicals - Air & $\begin{array}{l}\text { Positive: Iowa (0.7); Massachusetts (0.7); Pennsylvania (0.8); } \\
\text { South Carolina (-0.7); West Virginia (0.8); Wyoming (0.8) } \\
\text { Negative: Alabama (-0.7); Arizona (-0.7); California (-0.9); } \\
\text { North Dakota (-0.8); Ohio (-0.7); Oregon (-0.8) }\end{array}$ \\
\hline Population & $\begin{array}{l}\text { Positive: Alabama (1.0); Arizona (0.7); California (0.9); } \\
\text { Delaware (0.8); Nevada (0.7); Ohio (0.8); South Dakota (0.9); } \\
\text { Tennessee (0.8); Wyoming (0.8) } \\
\text { Negative: Arkansas (-0.9); Georgia (-0.8); Illinois (-0.9); } \\
\text { Minnesota (-0.9); Pennsylvania (-0.9); Vermont (-0.7); Virginia } \\
(-0.9)\end{array}$ \\
\hline State Expenditures & $\begin{array}{l}\text { Positive: Arizona (0.7); Arkansas }(0.8) \text {; California (1.0); } \\
\text { Delaware (0.8); Louisiana }(0.8) \text {; Nevada }(0.7) \text {; New Hampshire } \\
(0.8) \text {; North Dakota }(0.8) \text {; Oregon }(0.7) \text {; South Dakota; }(0.9) \text {; } \\
\text { Wyoming (0.9) } \\
\text { Negative: Georgia (-0.8); Illinois (-0.7); Minnesota (-0.7); } \\
\text { Pennsylvania (-0.9); Virginia (-0.9) }\end{array}$ \\
\hline $\begin{array}{l}\text { Gross State Product } \\
\text { (GSP) }\end{array}$ & $\begin{array}{l}\text { Positive: Alabama (0.7); Arizona (0.7); California (0.9); } \\
\text { Delaware }(0.8) \text {; Nevada }(0.8) \text {; } \\
\text { New Hampshire }(0.7) \text {; North Dakota }(0.9) ;\end{array}$ \\
\hline
\end{tabular}




\begin{tabular}{|l|l|}
\hline Category & State \\
\hline & Ohio (0.8); South Dakota (0.9); Wyoming (0.8) \\
& Negative: Arkansas (-0.9); Connecticut (-0.8); \\
& Georgia (-0.9); Idaho (-0.7); Illinois (-0.9); Michigan (-0.8); \\
& Minnesota (-0.9); New York (-0.7); Pennsylvania (-0.9); \\
& Virginia (-0.8); West Virginia (-0.7) \\
\hline GSP Mining \& & Positive: Georgia (0.7); Kentucky (0.9); Michigan (0.8); \\
Manufacturing (M\&M) & Nevada (0.7); North Dakota (0.9); Pennsylvania (0.9); Virginia \\
& $(0.9) ;$ Wyoming (0.8) \\
& Negative: Connecticut (-0.8); Iowa (-0.8); Tennessee (-0.8); \\
\hline & Utah (-0.7) \\
\hline
\end{tabular}

EE correlated with health rankings in only three states: Delaware, Louisiana, and Maryland. The correlation was negative which implies that as state spending on environmental programs increased, the health ranking score of these states decreased (went from a higher number to a lower number), which is a desirable effect. No positive correlations between EE and health rankings were present. This lack of an observed statistical connection between health rankings and EE for the majority of states may indicate that the environmental components used in the United Health Foundation index are under-weighted or that the influence of state environmental policy on public health is not significant.

EE correlated with unemployment rate in only six states: Kansas, Kentucky, Maryland, Rhode Island, Tennessee, and Washington. In two cases (Kentucky and Virginia), the correlation was negative indicating that unemployment decreased as state environmental expenditures increased. Within the remaining four states the EE-unemployment rate correlation was positive, with unemployment rate increasing as EE increased. Such a finding may imply that environmental expenditures by some state agencies do not play a role in either stimulating or retarding employment. Forty years after President Nixon reluctantly established EPA, the industrial/commercial sectors of the economy have largely adjusted to the regulatory paradigm in which they now must do business. It also is likely that other, more substantive econometric factors such as consumer demand, capital availability, and tax policy play a larger role in driving unemployment rates.

The quantity (pounds) of TRI regulated chemicals released to surface water in eight states (Arizona, Iowa, Nebraska, South Carolina, South Dakota, Vermont, West Virginia, and Wyoming) correlated with EE. In six of these states, as EE increased, the quantity of TRI regulated chemical released to surface water decreased. In two states (Arizona and Vermont) the opposite held true, an increase in state spending on environmental programs correlated with an increase in the quantity (pounds) of regulated chemical discharges into surface water.

A larger number of states, 12 or almost one-quarter of the study group, demonstrated a relationship between EE and the quantity of TRI regulated chemicals released into the atmosphere. EE correlated positively with TRI-regulated air discharges in six states (Iowa, Massachusetts, Pennsylvania, South Carolina, West Virginia and Wyoming) and negatively in the other six (Alabama, Arizona, California, North Dakota, Ohio, and Oregon). 
Other researchers have questioned the effectiveness that state regulatory agency programs have had on reducing discharges of TRI-regulated materials. Several studies relate changes (reductions) in TRI quantities to such factors as deliberate under-reporting, corporate responsiveness to consumer or community concerns, or pressure from stock-holders or investment groups (Grant and Jones, 2004).

For the correlations described in this paper, the effect that variations in economic output might have on TRI-related air discharges were considered by comparing GSP and M\&M GSP to the TRI-Air variable. Note that for the study period (2000 through 2009) GSP and M\&M GSP increased in each of the states, albeit at varying rates. This analysis found that there was a negative correlation between GSP and TRI-Air in 27 states, slightly more than half of the study group. As GSP increased, the quantity of TRI-regulated compounds discharged to the air in these states decreased. There were no positive correlations between GSP and TRI-Air values in any of the study group states. In eight states a correlation was noted between TRI-related air discharges and GSP Mining \& Manufacturing activity. Maine, New Hampshire, Pennsylvania, Virginia, and Wisconsin reported positive correlations between these variables while the correlations for Connecticut, Massachusetts, and Texas were negative.

The remaining four data sets: Population, State Expenditures, Gross State Product (GSP), and Gross State Product from Mining and Manufacturing (M\&M GSP) have the highest number of individual state correlations to EE, ranging from 24 percent (12 states for M\&M GSP) to 43 percent ( 21 states for GSP). These variables are interconnected in a manner that makes separating individual relationships difficult.

Average population growth in the United States between 2000 and 2009 was 7.6 percent. As population increases, so do: (a) tax revenues, (b) community growth/density near industrial or commercial sites, and (c) demands for constituent service. Total state expenditures are positively correlation to population in all but six states (Connecticut, Idaho, Louisiana, Michigan, Rhode Island, and West Virginia) where no correlation with population is apparent. Four of these states (Louisiana, Michigan, Rhode Island, and West Virginia) had population growth of less than one percent, the lowest increases reported for the study group.

Similarly, expansion in GSP and M\&M GSP improves the tax base, making revenues more available to state agencies as well as possibly increasing the necessity of implementing magnified or more robust regulatory inspection and enforcement programs. These factors may apply upward pressure to EE bud gets. This type of relationship seems to be borne out in ten states (Table 1) where the correlation between EE and GSP was positive: as GSP increased, EE also increased. Feiock and Stream (2001) and Rhu et al. (2007) explore this and similar rationales underlying state budgets and examine the connections between state expenditures and the availability of funding for environmental programs.

EE correlations with GSP in 11 other states were negative, describing a relationship of increasing GSP and decreasing environmental expenditures. However, nine of these 11 
states $^{1}$ also report a negative correlation between $\mathrm{EE}$ and total state expenditures. This implies that factors other than GSP may be affecting state spending in these negative relationship states.

There are 16 states where population correlates with EE. Data from nine states demonstrates that as population increased, so did EE, a positive correlation. These states reported an average population growth between 2000 and 2009 of 12 percent. Pearson's moment correlation calculations for population and EE data from the other seven states resulted in a negative correlation - as population increased, EE decreased. These states reported average population growths of less than seven percent between 2000 and 2009.

The last relationship examined was that between $\mathrm{EE}$ and state expenditures. There are five states (Georgia, Illinois, Minnesota, Pennsylvania, and Virginia) where EE is negatively correlated with state expenditures, with EE spending decreasing as overall state spending increased. These same five states also reported a negative correlation between population and EE. In the 11 other states where a correlation was found to be present between state expenditures and EE, it was positive - as overall state expenditures rose, so did environmental expenditures.

\section{Discussion}

While federal rules provide a basic regulatory framework, each state environmental program is organized differently and is centered largely on local and regional factors specifically related to its constituency, economy, and political culture. Further elucidating the correlations described here for any individual state will require additional, in-depth, contextual knowledge or appreciation of state-specific drivers. While the apparent relationships identified in this paper tell a mixed story, some broad patterns are apparent.

Population (in 15 states), GSP (in 21 states), M\&M GSP (in 12 states) and total state expenditures (in 17 states) are the independent variable data sets that seem to have the most connection with environmental expenditures. Each of these ties directly to the overall financial capacity of a state and they are roughly split in defining positive and negative relationships.

Out of the 49 states evaluated, TRI-regulated air and water discharges correlated with EE in only 12 and eight states, respectively. This tends to lend credence to several other researchers suspicions that these types of releases are little influenced by state programmatic activities (Fung and O'Rourke, 2000; Kerret and Gray, 2007; and Connors et al., 2013). However, TRI regulated air and water discharges show a negative correlation in 42 states: as the quantity of contaminants to the air decreased, the amount of TRI-regulated compounds discharged to water increased. This may indicate a corporate preference to address air pollutants versus managing those entering surface water.

Changes in unemployment rate and health ranking apparently have little to no connection with spending on environmental programs. The unemployment rate independent variable

\footnotetext{
${ }^{1}$ Idaho, New York, and West Virginia report correlation coefficients of -0.6 between EE and GSP. The other six states (Arkansas, Georgia, Illinois, Minnesota, Pennsylvania, and West Virginia) have correl ation coefficients of -0.7 or greater.
} 
was correlated to EE in six states, while the health ranking independent variable correlated with EE in three states. In 10 states, health rankings correlated negatively with M\&M GSP as M\&M GSP increased, health ranking decreased; which is a desirable outcome. Four states showed a positive correlation between health ranking and M\&M GSP; indicating a possible relationship between the amount of manufacturing and mining within these states and the overall quality of public health.

Causative associations between independent variable data sets (population, gross state product, etc.) and environmental expenditures have not been established and are not postulated as part of this work. Additional, more robust statistical analysis and compilation of other supplementary data sets would be needed before those types of relationships could be suggested. However, the associations described tend to make empirical, if not definitively quantitative sense. It is likely that further analyses will uncover deeper connectio ns between multiple independent variables and how they influence environmental expenditures.

\section{References}

Agthe, D. E., Bilings, R. B., \& Marchand, J. R. (1996). Socioeconomic and political determinants of state spending on environmental programs. American Economist, 40, 24-30.

Bacot, H. A., \& Dawes, R. A. (1997). State expenditures and policy outcomes in environmental program management. Policy Studies Journal, 25(3), 355-370. DOI: $10.1111 / \mathrm{j} .1541$ - 0072.1997.tb00027.x

Blakeslee, M. E., \& Rong, F. (2006). State environmental agency contributions to enforcement and compliance: 200-2003. Washington, DC: Environmental Council of the States.

Brown, R. S., \& Green, V. (2001). Report to Congress: State environmental agency contributions to enforcement and compliance. Washington, DC: Environmental Council of the States.

Connors, E., Johnston, H. H., \& Gao, L. S. (2013). The informational value of toxic release inventory performance. Sustainability Accounting, Management \& Policy Journal, 4(1), 32-55. http://dx.doi.org/10.1108/S AMPJ-01-2011-0003

Crotty, P. M. (1987). The new federalism game: Primacy implementation of environmental policy. Publius: The Journal of Federalism, 17(Spring), 53-67. http://www.jstor.org/s table/3329934

Feiock, R. C., \& Stream, C. (2001). Environmental protection versus economic development: A false trade-off? Public Administration Review, 61(6), 313-321. http://d x.doi.org/10.1111/0033-3352.00032

Fung, A., \& O'Rourke, D. (2000). Reinventing environmental regulation from the grassroots up: Explaining and expanding the success of the toxics release inventory. Environmental Management, 25(2), 115-127. http://dx.doi.org/10.1007/s002679910009

Giles, C. (2013). Next generation compliance. The Environmental Forum, 
September-October, 22-26.

Grant, D., \& Jones, A. W. (2004). Do manufacturers pollute less under the regulation-through-information regime? What plant-level data tell us. The Sociological Quarterly, 45(3), 471-486. http://dx.doi.org/10.1111/j.1533-8525.2004.tb02299.x

James, J., Eisen, L., \& Subramanian, R. (2012). A view from the states: Evidence-based public safety legislation. The Journal of Criminal Law \& Criminology, 102(3), 821-849.

Kerret, D., \& Gray, G. M. (2007). What do we learn from emissions reporting? Analytical considerations and comparison of pollutant release and transfer registers in the United States, Canada, England, and Australia. Risk Analysis, 27(1), 203-223. http://d x.doi.org/10.1111/j.1539-6924.2006.00870.x

Konisky, D. M., \& Woods, N. D. (2012). Measuring state environmental policy. Review of Policy Research, 29(4), 544-569. http://dx.doi.org/10.1111/j.1541-1338.2012.00570.x

Lester, J. P., \& Bowman, A. (1989). Implementing environmental policy in a federal system: A test of the Sabatier-Mazmainian model. Polity, 21(Summer), 731-753. http://dx.doi.org/10.2307/3234721

Mintz, J. A. (2013). Assessing national environmental enforcement: Some lessons from the United States' experience. The Georgetown International Environmental Law Review, 26(1), $1-12$.

Mohapatra, S., \& Mishra, P. (2011). Composition of public expenditure on health and economic growth: A cointegration analysis and causality testing. IUP Journal of Public Finance, 9(2), 30-43.

Newmark, A. J., \& Witko, C. (2007). Pollution, politics, and preferences for environmental spending in the states. Review of Policy Research, 24(4), 291. http://d x.doi.org/10.1111/j.1541-1338.2007.00284.x

Patten, D. M. (1998). The impact of EPA's TRI disclosure program on state environmental and natural resource expenditures. Journal of Accounting and Public Policy, 17, 367-382. http://dx.doi.org/10.1016/S0278-4254(98)10011-X

Ryu, J. E., Bowling, C. J., Cho, C., \& Wright, D. S. (2007). Effects of administrators' aspirations, political principals' priorities, and interest groups' influence on state agency budget requests. Public Budgeting \& Finance, 27(2), 22-49. http://d x.doi.org/10.1111/j.1540-5850.2007.00873.x

Stafford, S. L. (2008). Self-policing in a targeted enforcement regime. Southern Economic Journal, 74(4), 934-951.

Steinway, D. M., \& Botts, B. (2005). Fundamentals of environmental law. In T. F. P. Sullivan (Ed.), Environmental law handbook (18th ed., pp. 1-64). Lanham, Maryland: Government Institutes.

Toffel, M. W., \& Short, J. (2011). Coming clean and cleaning up: Does voluntary 


\section{Macrothink}

Journal of Environment and Ecology ISSN 2157-6092 2014, Vol. 5, No. 2

self-reporting indicate effective self-policing. Journal of Law and Economics, 54(August), 609-649. http://dx.doi.org/10.1086/658494

United Health Foundation. (2014). America's Health Rankings. Retrieved July 28, 2014 from http://www. unitedhealthfoundation.org/Publications/AHR.aspx

United States General Accounting Office (GAO). (1988). School finance: State efforts to equalize funding between wealthy and poor school districts GAO/HEHS-98-92)

Welborn, D. M. (1988). Conjoint federalism and environmental regulation in the United States. Publius: The Journal of Federalism, 18(Winter), 27-43.

Woods, N. D. (2005). Primacy implementation of environmental policy in the U.S. states. Publius: The Journal of Federalism, 36(2), 259-276. http://dx.doi.org/10.1093/publius/pji029

\section{Copy right Disclaimer}

Copyright for this article is retained by the author, with first publication rights granted to the journal.

This is an open-access article distributed under the terms and conditions of the Creative Commons Attribution license (http://creativecommons.org/licenses/by/3.0/). 